
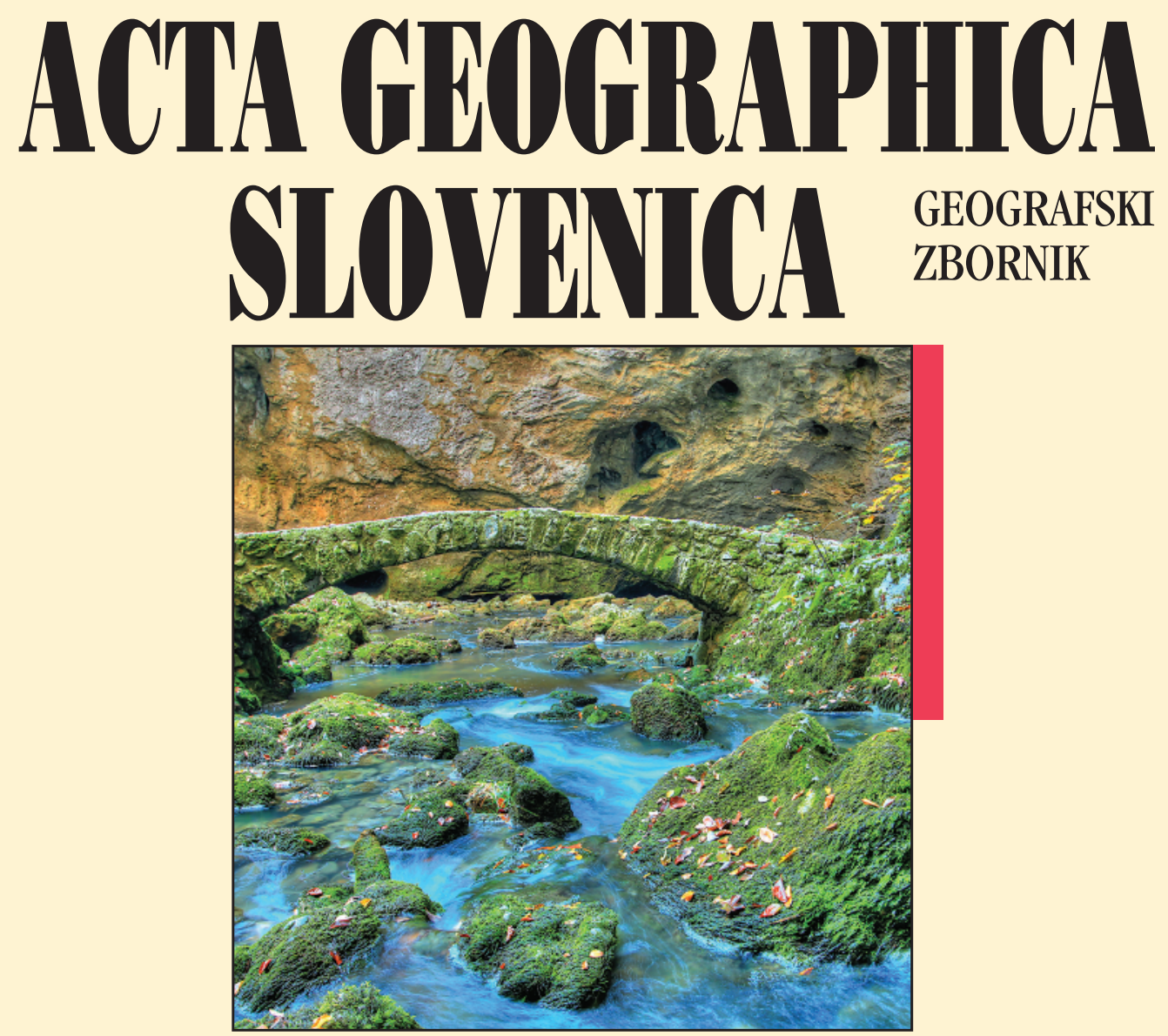


\section{ACTA GEOGRAPHICA SLOVENICA GEOGRAFSKI ZBORNIK \\ 59-1 • 2019}

\section{Contents}

Maja KOCJANČIČ, Tomislav POPIT, Timotej VERBOVŠEK

Gravitational sliding of the carbonate megablocks in the Vipava Valley, SW Slovenia

Małgorzata KIJOWSKA-STRUGAŁA, Anna BUCAŁA-HRABIA

Flood types in a mountain catchment: the Ochotnica River, Poland

Irena MOCANU, Bianca MITRICĂ, Mihaela PERSU

Socio-economic impact of photovoltaic park: The Giurgiu county rural area, Romania

Andrej GOSAR

The size of the area affected by earthquake induced rockfalls: Comparison of the 1998 Krn Mountains (NW Slovenia) earthquake $\left(M_{w} 5.6\right)$ with worldwide data

Matej GABROVEC, Peter KUMER

Land-use changes in Slovenia from the Franciscean Cadaster until today

Mojca FOŠKI

Using the parcel shape index to determine arable land division types

Mateja FERK, Matej LIPAR, Andrej ŠMUC, Russell N. DRYSDALE, Jian ZHAO

Chronology of heterogeneous deposits in the side entrance of Postojna Cave, Slovenia

\section{Special issue - Green creative environments}

Jani KOZINA, Saša POLJAK ISTENIČ, Blaž KOMAC

Green creative environments: Contribution to sustainable urban

and regional development

Saša POLJAK ISTENIČ

Participatory urbanism: creative interventions for sustainable development

Jani KOZINA, Nick CLIFTON

City-region or urban-rural framework: what matters more in understanding

the residential location of the creative class?

Matjaž URŠIČ, Kazushi TAMANO

The importance of green amenities for small creative actors in Tokyo:

Comparing natural and sociocultural spatial attraction characteristics

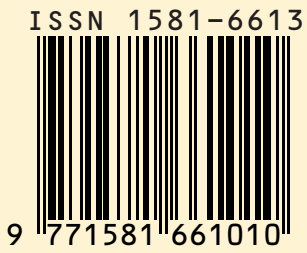




\section{ACTA GEOGRAPHICA SLOVENICA}

$59-1$

2019

ISSN: 1581-6613

COBISS: 124775936

UDC/UDK: 91

(C) 2019, ZRC SAZU, Geografski inštitut Antona Melika

International editorial board/mednarodni uredniški odbor: David Bole (Slovenia), Michael Bründl (Switzerland), Rok Ciglič (Slovenia), Matej Gabrovec (Slovenia), Matjaž Geršič (Slovenia), Peter Jordan (Austria), Drago Kladnik (Slovenia), Blaž Komac (Slovenia), Andrej Kranjc (Slovenia), Dénes Lóczy (Hungary), Simon McCharty (United Kingdom), Slobodan Marković (Serbia), Janez Nared (Slovenia), Drago Perko (Slovenia), Marjan Ravbar (Slovenia), Nika Razpotnik Visković (Slovenia), Aleš Smrekar (Slovenia), Annett Steinführer (Germany), Mimi Urbanc (Slovenia), Matija Zorn (Slovenia)

Editor-in-Chief/glavni urednik: Blaž Komac; blaz@zrc-sazu.si

Executive editor/odgovorni urednik: Drago Perko; drago@zrc-sazu.si

Chief editor for physical geography/glavni urednik za fizično geografijo: Matija Zorn; matija.zorn@zrc-sazu.si Chief editor for human geography/glavna urednica za humano geografijo: Mimi Urbanc; mimi@zrc-sazu.si

Chief editor for regional geography/glavni urednik za regionalno geografijo: Drago Kladnik; drago.kladnik@zrc-sazu.si

Chief editor for spatial planning/glavni urednik za regionalno planiranje: Janez Nared; janez.nared@zrc-sazu.si

Chief editor for rural geography/glavna urednica za geografijo podeželja: Nika Razpotnik Visković; nika.razpotnik@zrc-sazu.si Chief editor for urban geography/glavni urednik za urbano geografijo: David Bole; david.bole@zrc-sazu.si

Chief editor for geographic information systems/glavni urednik za geografske informacijske sisteme: Rok Ciglič; rok.ciglic@zrc-sazu.si

Chief editor for environmental protection/glavni urednik za varstvo okolja: Aleš Smrekar; ales.smrekar@zrc-sazu.si

Editorial assistant/uredniški pomočnik: Matjaž Geršič; matjaz.gersic@zrc-sazu.si

Issued by/izdajatelj: Geografski inštitut Antona Melika ZRC SAZU

Published by/založnik: Založba ZRC

Co-published by/sozaložnik: Slovenska akademija znanosti in umetnosti

Address/Naslov: Geografski inštitut Antona Melika ZRC SAZU, Gosposka ulica 13, SI - 1000 Ljubljana, Slovenija

The papers are available on-line/prispevki so dostopni na medmrežju: http://ags.zrc-sazu.si (ISSN: 1581-8314)

Ordering/naročanje: Založba ZRC, Novi trg 2, p. p. 306, SI - 1001 Ljubljana, Slovenija; zalozba@zrc-sazu.si

Annual subscription/letna naročnina: $20 €$ for individuals/za posameznike, $28 €$ for institutions/za ustanove.

Single issue/cena posamezne številke: $12,50 €$ for individuals/za posameznike, $16 €$ for institutions/za ustanove.

Cartography/kartografija: Geografski inštitut Antona Melika ZRC SAZU

Translations/prevodi: DEKS, d. o. o.

DTP/prelom: SYNCOMP, d. o. o.

Printed by/tiskarna: Tiskarna Present, d. o. o.

Print run/naklada: 350 copies/izvodov

The journal is subsidized by the Slovenian Research Agency and is issued in the framework of the Geography of Slovenia core research programme (P6-0101)/revija izhaja s podporo Javne agencije za raziskovalno dejavnost Republike Slovenije in nastaja v okviru raziskovalnega programa Geografija Slovenije (P6-0101).

The journal is indexed also in/revija je vključena tudi v: SCIE - Science Citation Index Expanded, Scopus, JCR - Journal Citation Report/Science Edition, ERIH PLUS, GEOBASE Journals, Current geographical publications, EBSCOhost, Geoscience e-Journals, Georef, FRANCIS, SJR (SCImago Journal \& Country Rank), OCLC WorldCat, Google scholar, and CrossRef

Oblikovanje/Design by: Matjaž Vipotnik.

Front cover photography: Stone bridge over the Rak River on the outskirts of the Rakov Škocjan polje, which is otherwise known for its beautiful natural bridges (photograph: Matej Lipar).

Fotografija na naslovnici: Kamniti most čez reko Rak na obrobju kraškega polja Rakov Škocjan, ki je sicer bolj znano po čudovitih naravnih mostovih (fotografija: Matej Lipar). 


\section{GREEN CREATIVE ENVIRONMENTS: CONTRIBUTION TO SUSTAINABLE URBAN AND REGIONAL DEVELOPMENT}

Jani Kozina, Saša Poljak Istenič, Blaž Komac

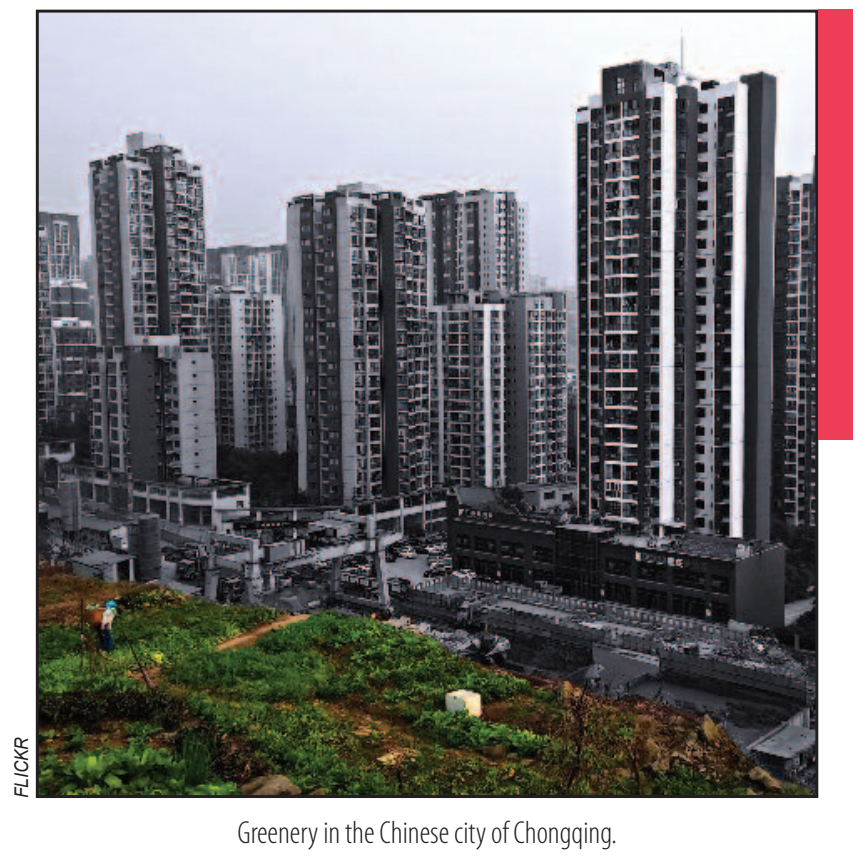


DOI: https://doi.org/10.3986/AGS.7030

UDC: $911.375: 502.131 .1$

$711.2: 502.131 .1$

COBISS: 1.01

\title{
Green creative environments: Contribution to sustainable urban and regional development
}

\begin{abstract}
The aim of this paper is to provide a theoretical and conceptual introduction for the Special Issue on the role of green creative environments in sustainable urban and regional development. The idea is based on the assumption that concepts of creativity mostly address economic issues and to a lesser extent social issues, while green concepts predominantly deal with environmental aspects. Therefore, we lack a deeper insight into the interrelations between creative and green environments in urban and regional development. This special issue addresses this research gap through investigating 1 ) the residential preferences of the creative class in city-regional, urban and rural settings, 2) participatory urbanism as a tool for creative interventions in urban planning, and 3) the importance of green amenities as spatial attraction factors for small creative actors. We argue that green creative environments can contribute to sustainable urban and regional development.
\end{abstract}

KEY WORDS: creativity, innovation, sustainability, nature, creative city, green city, creative industries, natural amenities

\section{Zelena ustvarjalna okolja: prispevek k trajnostnemu urbanemu in regionalnemu razvoju}

Namen tega prispevka je prispevati teoretski in konceptualni uvod v posebno izdajo o vlogi zelenih ustvarjalnih okolij v trajnostnem urbanem in regionalnem razvoju. Ideja temelji na predpostavki, da koncepti ustvarjalnosti večinoma obravnavajo ekonomska vprašanja in v manjši meri socialna vprašanja, zeleni koncepti pa se pretežno ukvarjajo z okoljskimi vidiki. Zato v urbanem in regionalnem razvoju nimamo globljega vpogleda v medsebojne povezave med ustvarjalnimi in zelenimi okolji. Posebna izdaja revije obravnava to raziskovalno vrzel s preučevanjem 1) bivanjskih preferenc ustvarjalnega razreda v regionalnih, mestnih in podeželskih okoljih, 2) participativnega urbanizma kot orodja za ustvarjalne posege v urbanistično načrtovanje in 3) pomena zelenih dobrin kot dejavnika prostorske privlačnosti za male ustvarjalne akterje. Trdimo, da zelena ustvarjalna okolja lahko prispevajo k trajnostnemu urbanemu in regionalnemu razvoju.

KLJUČNE BESEDE: ustvarjalnost, inovacije, trajnostnost, narava, ustvarjalna mesta, zelena mesta, ustvarjalne dejavnosti, naravne dobrine

\section{Jani Kozina, Blaž Komac}

Research Centre of the Slovenian Academy of Sciences and Arts, Anton Melik Geographical Institute jani.kozina@zrc-sazu.si,blaz@zrc-sazu.si

\section{Saša Poljak Istenič}

Research Centre of the Slovenian Academy of Sciences and Arts, Institute of Slovenian Ethnology sasa.poljak@zrc-sazu.si

The paper was submitted for publication on September $28^{\text {th }}, 2018$.

Uredništvo je prejelo prispevek 28. septembra 2018. 


\section{Introduction}

This special issue is taking into consideration two distinct, but interrelated fields in urban and regional development. The first issue refers to creativity and related concepts such as creative industries, creative economy, and the creative class. The second issue pertains to the natural environment, which can be associated with concepts such as green infrastructure, green economy, greenery, ecosystem services, and nature-based solutions. Both are heavily cited as significant factors of sustainable urban and regional development (Ravbar, Bole and Nared 2005; Bole 2008; Ravbar 2011; Mell et al. 2013; Clifton, Comunian and Chapain 2015; Smrekar, Šmid Hribar and Erhartič 2015; Uršič 2016; Bowen and Lynch 2017; Kozina and Bole 2017; Kozina 2018; Lazzeretti, Capone and Innocenti 2018), but from different aspects and in different manners. Whereas the »creative city « mostly addresses economic and to a minor degree social issues (Pratt and Hutton 2013), the »green city « predominantly deals with environmental features (Brilhante and Klaas 2018). However, the line between them is subtle. The creative economy and creative jobs are not easily identified and measured (Boggs 2009) and the same is true of green economy and green jobs (Muro, Rothwell and Saha 2011). Cooke (2013) reports that "eco-innovation" on the one hand and creative industries analysis on the other have largely operated in sealed containers or intellectual »silos«. Stolarick and Smirnova (2015) argue that clean, green, creative, and smart cities have all been separately identified, measured, ranked, and evaluated. So there is a need to take these concepts and their potential interrelations into deeper consideration.

The roots of the creative city movement can be sought in a discourse of a post-industrial society that has seen a shift from traditional manufacturing to new agents of growth such as knowledge, creativity, and innovation (Bell 1973; Scott and Storper 2015; Florida 2002; 2005; 2008). In the 1980s, the "cultural turn" moved attention away from the Marxist tradition towards culture by favouring cultural industries (Garnham 2005) that refer to the traditional cultural economics and to forms of cultural production characterised by symbolic elements (Lazzeretti, Capone and Innocenti 2018). Since the 1990s, the »creative turn « has denoted the dawn of a new era in political and academic domains by constructing creative industries and later the creative economy as a policy object that can be managed to secure primarily economic, but also occasionally social outcomes so as to increase competitiveness (Schlesinger 2017; Kozina and Bole 2018). The focus of cities, regions, and countries across the world has thus been redirected to the importance of creativity and innovation in fostering development with the emergence of highly interrelated concepts such as creative industries, creative economy, and the creative class (Chapain, Clifton and Comunian 2013).

The origins of the green city movement can be associated with rapid urbanisation, industrialisation, and the deterioration of urban environmental performance in the $20^{\text {th }}$ century (Brilhante and Klaas 2018). As a response to pressing challenges in the 1980s, strong voices emerged to reconcile economic growth, environmental preservation, and social development (WCED 1987). The new millennium has seen the "green turn" as a response to the global ecological crises and the accumulating evidence of rising inequality (Bina and La Camera 2011). It signifies a new privileging of listening to consumer demand for more usable, less over-engineered, more sustainable goods and services (Cooke 2010). To address these issues, modern cities apply collective approaches to the use and management of green spaces in urban social-ecological systems. This form of social-ecological innovation provides a valuable resource in the production and adaptive management of local ecosystem services (Dennis and James 2018).

At the moment, we lack more detailed theoretical and empirical contributions about the interrelations between creativity and natural environment in urban and regional development. This special issue addresses this challenge by focusing on selected examples of:

1) residential preferences of the creative class in city-regional, urban, and rural settings,

2) participatory urbanism as a tool for creative interventions in urban planning,

3) the importance of green amenities as spatial attraction factors for small creative actors.

However, the aim of the special issue and the following contributions is not to comprehensively address the role of green creative environments in urban and regional development. Instead, it wants to reveal some hidden aspects in analysing the connection between creativity and the natural environment and unveil the potential spatial implications of their synergies. A shift is needed in how we mutually reflect the creativity and the environment. The changing nature of the society, the economy, and the environment demands new solutions for governance and communication. We argue that by focusing on green creative environments, we can begin to near sustainable urban and regional development and a high quality of life. 


\section{Natural environments: a missing aspect in studying the impact of creativity on urban and regional development?}

The impact of the natural environment on creative and knowledge-intensive processes has been analysed by various disciplines such as psychology, interior design, education and health studies, landscape architecture, etc. A large body of evidence shows that interaction with greenery can be beneficial for reducing stress and improving emotional states and cognitive function (Van Den Bogerd et al. 2018). The environment, including green areas discussed here, influences creativity, because a connection to nature enhances creative performance (van Rompay and Tineke 2016) and is associated with innovative and holistic cognitive styles (Leong, Fischer and McClure 2014). Nature plays a role especially in the preparation phase and the incubation phase of the creative process (Plambech and Konijnendijk van den Bosch 2015).

The impact of greenery has a significant impact on creativity within indoor physical environments (Dul and Ceylan 2011; Caple 2019) and also when it is exposed to outdoor natural environments (Plambech and Konijnendijk van den Bosch 2015). For this reason, connectedness with nature should be promoted in schools, workplaces, and at home (Leong, Fischer and McClure 2014). Green areas can contribute to new ways of understanding modern environmental issues such as noise, pollution, and other hazards in urban and rural areas where new creative and innovative solutions are constantly being pursued.

In spite of abundant evidence of the highly positive impact natural environment has on creativity, the research in urban and regional science offers only limited proof to support such relations. Proximity to the natural environment as part of the so-called »soft « factors such as diversity, openness, amenities, and tolerance plays only a marginal role in attracting creative and high-skilled workers to a particular place. However, these factors play a more important role in retaining the creative capital in a given area, which justifies policies aimed at retaining people rather than attracting them (Martin-Brellot et al. 2010). Professional and social relations, other types of local social connections related to people's life courses, and so-called »hard « conditions, especially job availability, seem to be the more relevant drivers of creative urban and regional development (Musterd and Gritsai 2012). The reasons for such outcomes are at least twofold. First, recent studies on regional creative capacity often focus on the urban context without taking into account the rural settings (Gülümser, Baycan-Levent and Nijkamp 2010), which exhibit a more prominent role of the natural environment. As reported by some authors, attraction to rural areas might be significantly attributed to an access to outdoor amenities and activities (McGranahan and Wojan 2007; White 2010). Second, creativity in urban and regional development has been mostly applied through the »culture-centric « and "econo-centric « approach (Andres and Chapain 2013), which has neglected the ecological perspective of sustainability.

This brings us back to the initial question: what is the relation between green and creative environments? Are these two different concepts in their own right or do they share some commonalities? Cooke $(2013 ; 2015)$ tried to merge the two central themes of this special issue through »eco-innovation « and »ecoart «. These two conceptualizations imply that synergies between creativity and greenery are relevant to promoting sustainability. However, the connection between them is undermined by Stolarick and Smirnova (2015), who offer a rare example of statistical comparative analysis of green, sustainable, creative, and smart cities. Their findings suggest that these concepts are different and measured differently. While each may have its own importance and value to many regions for various reasons, they are different dimensions that are quite independent of each other - at least currently and by using the available measures. This kind of argumentation calls for additional in-depth research into the connection between creativity and the natural environment in urban and regional development.

\section{Ljubljana as an example of a green creative city}

One of the starting points for preparing this special issue was the conference »Creative Green Ljubljana: From Theory to Practice«, organized in 2016 by the Research Centre of the Slovenian Academy of Sciences and Arts and Poligon Creative Centre. Its aim was to accelerate the flow of knowledge and information in the field of creative industries, but with the focus on green aspects, since Ljubljana at that time celebrated and promoted its European Green Capital 2016 Award. Ten researchers from diverse disciplines discussed how developed the cultural and creative industries in Slovenia are and what is their role in a sus- 
tainable economy. They also analysed which socio-cultural projects and initiatives creatively support a sustainable and participatory development of Ljubljana and indicated how such activities can contribute to social innovation while preserving the environment.

Ljubljana proved a good point of departure for discussions; besides promoting its green qualities (being a European Green Capital 2016, Global Top 100 Sustainable Destination, World's Best Sustainable Destination etc.), it has been heavily branded with its »culture« and »creativity« (e.g. as the 2010 World Book Capital and the 2015 UNESCO City of Literature). This reflects the city's strategy to intertwine cultural and green measures, which has proved particularly successful for its current development. The common denominator of both concepts is a notion of the "quality of life«: the goal cities are striving for in order to attract inhabitants, tourists, companies, and investment bringing in new revenues of economic and human capital (Poljak Istenič 2016). However, the quality of life always depends on sustainability, as the cities must maintain the capacity to meet its residents' future needs in relation to just ecological, economic, and social systems (Evans 2002). Yet, the link between creativity, sustainability (or green urban policies and measures ensuring it), and the quality of life is often unclear or even contested, thus, it calls for further elaboration.

\section{Filling the gaps: papers of the special issue}

The special issue fills some gaps in studying the interrelations between creativity and the natural environment in urban and regional development. The selected examples encompass 1) the residential preferences of the creative class in city-regional, urban, and rural settings, 2) participatory urbanism as a tool for creative interventions in urban planning, and 3) the importance of green amenities as spatial attraction factors for small creative actors.

The first paper by Kozina and Clifton (2019) addresses the question on what matters more in understanding the residential location of the creative class in Slovenia: the city-region or the urban-rural framework? Their analysis shows that differences in residential concentrations of the creative class vary more within city-regions (on an urban-rural framework) than between city-regions. Moreover, the creative class is moving out of densely populated urban areas to more sparsely populated suburban and rural areas within all city-regions. Their research indicate that the new models of living promote dispersion. Subsequently, the authors contest the claim that creative-knowledge activities are fundamentally a predominantly urban-centric phenomenon. In the long run, they seem to become impregnated by a mixture of rurality and suburbanity with a more prominent role of the natural environment.

Shifting the focus of the analysis from rural to urban settings, the paper by Poljak Istenič (2019) presents the concept of participatory urbanism as a tool for creative interventions in urban planning and analyses its practical implications in the context of the City of Ljubljana. It assesses the potential of participatory methodology for physical and social interventions in public spaces through the case-studies of two creative spatial practices: the Onkraj gradbišča/Beyond the construction site urban community garden and the community-led renovation of the Savsko naselje neighbourhood. The cases show how bottom-up initiatives can contribute to the sustainable development of an urban area, especially to its environmental and social features. The paper concludes with ideas on how cities might engage with bottom-up spatial practices to increase the effectiveness of urban spatial planning, management, and administration and to boost their green creative image.

Closing this special issue, the paper by Uršič and Tamano (2019) investigates the importance of green amenities for small creative actors in Tokyo. In the last decade, the Japanese authorities have invested considerable effort and economic resources into constructing developmental models that can help build a friendlier environment for the domestic creative economy. Based on an analysis of spatial attraction factors for individuals of various creative occupations, the authors identify how important green or natural amenities are in comparison with other sociocultural characteristics regarding small creative groups. The analysis of data acquired through semi-structured interviews indicates that green amenities do not play a primary role in the spatial distribution of small creative groups, but they do play a very important secondary role in cases when creative workers consider places with similar spatial attraction characteristics in Tokyo's specific areas. 


\section{Conclusion}

The aim of the special issue is to contribute new evidence to the studies of urban and regional development by unveiling the connections between creativity and nature. The idea is based on the assumption that the concepts of creativity mostly address economic and to a lesser extent social issues (Pratt and Hutton 2013), while green concepts predominantly deal with environmental features (Brilhante and Klaas 2018). The "creative city«, the "green city«, and other similar paradigms are all useful when addressing the challenges caused by the (de)industrialisation and urbanisation of recent decades. These are related to the transformed post-industrial way of production and consumption and associated environmental pressures. Although the link between creativity and the natural environment seems quite obvious in this regard, the literature offers quite a limited set of theoretical and practical contributions. For this reason, the authors of this special issue have cross-pollinated the two fields of interest by searching for their interrelations.

The main findings suggest that agglomeration logics do not necessarily apply when studying the relationship between urban hierarchy and the distribution of the creative economy. Thus, urban and regional planners should also invest in rural/suburban localities with a significant extent of natural amenities and the increasing amount of creative and knowledge workers. However, green infrastructure should also be promoted in urban areas, especially when trying to retain talent in certain districts. Merging green environments and practices with participatory and collective actions can then boost urban development. Cities should simultaneously invest in physical and social green infrastructure in order to reach their ultimate goal: a high quality of life of its citizens.

ACKNOWLEDGEMENT: This work was supported by the Slovenian Research Agency (ARRS) program Geography of Slovenia (P6-0101) and the project Surviving, living, thriving: Creativity as a way of life (Z6-6841).

\section{References}

Andres, L., Chapain, C. 2013: The integration of cultural and creative industries into local and regional development strategies in Birmingham and Marseille: Towards an inclusive and collaborative governance? Regional Studies 47-2. DOI: https://doi.org/10.1080/00343404.2011.644531

Bell, W. 1973: The coming of post-industrial society. New York.

Bina, O., La Camera, F. 2011: Promise and shortcomings of a green turn in recent policy responses to the »double crisis«. Ecological Economics 70-12. DOI: https://doi.org/10.1016/j.ecolecon.2011.06.021

Boggs, J. 2009. Cultural industries and the creative economy - Vague but useful concepts. Geography Compass 3-4. DOI: https://doi.org/10.1111/j.1749-8198.2009.00247.x

Bole, D. 2008: Cultural industry as a result of new city tertiarization. Acta geographica Slovenica 48-2. DOI: https://doi.org/10.3986/AGS48202

Bowen, K. J., Lynch, Y. 2017: The public health benefits of green infrastructure: the potential of economic framing for enhanced decision-making. Current Opinion in Environmental Sustainability 25. DOI: https://doi.org/10.1016/j.cosust.2017.08.003

Brilhante, O., Klaas, J. 2018: Green city concept and a method to measure green city performance over time applied to fifty cities globally: Influence of GDP, population size and energy efficiency. Sustainability 10-6. DOI: https://doi.org/10.3390/su10062031

Caple, D. 2019: Creativity in design of green workplaces. Proceedings of the 20th Congress of the International Ergonomics Association (IEA 2018). IEA 2018. Advances in Intelligent Systems and Computing 824. Cham. DOI: https://doi.org/10.1007/978-3-319-96071-5_10

Chapain, C., Clifton, N., Comunian, R. 2013: Understanding creative regions: Bridging the gap between global discourses and regional and national contexts. Regional Studies 47-2. DOI: https://doi.org/10.1080/ 00343404.2013 .746441

Clifton, N., Comunian, R., Chapain, C. 2015: Creative regions in Europe: Challenges and opportunities for policy. European Planning Studies 23-12. DOI: https://doi.org/10.1080/09654313.2015.1104815

Cooke, P. 2010: Regional innovation systems: development opportunities from the "green turn«. Technology Analysis \& Strategic Management 22-7. DOI: https://doi.org/10.1080/09537325.2010.511156 
Cooke, P. 2013: Complexity geography and the rise of the green creative city. Creative Industries and Innovation in Europe: Concepts, measures and comparative case studies. Abingdon.

Cooke, P. 2015: The resilience of sustainability, creativity and social justice from the arts \& crafts movement to modern day »eco-painting«. City, Culture and Society 6-3. DOI: https://doi.org/10.1016/j.ccs.2015.02.003

Dennis, M., James, P. 2018: Urban Social-ecological Innovation: Implications for Adaptive Natural Resource Management. Ecological Economics 150. DOI: https://doi.org/10.1016/j.ecolecon.2018.04.005

Dul, J., Ceylan, C. 2011: Work environments for employee creativity. Ergonomics 54-1. DOI: https://doi.org/ $10.1080 / 00140139.2010 .542833$

Evans, P. 2002: Introduction: Looking for agents of urban livability in a globalized political economy. Livable cities? Urban struggles for livelihood and sustainability. Berkeley, Los Angeles.

Florida, R. 2002: The rise of the creative class: And how it's transforming work, leisure, community and everyday life. New York.

Florida, R. 2005: The flight of the creative class: the new global competition for talent. New York.

Florida, R. 2008: Who's your city? How the creative economy is making where you live the most important decision of your life. New York.

Garnham, N. 2005: From cultural to creative industries. International Journal of Cultural Policy 11-1. DOI: https://doi.org/10.1080/10286630500067606

Gülümser, A. A., Baycan-Levent, T., Nijkamp, P. 2010: Measuring regional creative capacity: A literature review for rural-specific approaches. European Planning Studies 18-4. DOI: https://doi.org/10.1080/ 09654311003593614

Kozina, J. 2018: Demographic characteristics of creative workers: under-activated development potentials in Slovenia? Acta geographica Slovenica 58-2. DOI: https://doi.org/10.3986/AGS.4602

Kozina, J., Bole, D. 2017. Creativity at the European periphery: Spatial distribution and developmental implications in the Ljubljana Region. Creative Industries in Europe: Drivers of New Sectoral and Spatial Dynamics. Cham. DOI: https://doi.org/10.1007/978-3-319-56497-5_11

Kozina, J., Bole, D. 2018: The impact of territorial policies on the distribution of the creative economy: tracking patterns of spatial innovation in Slovenia. Hungarian Geographical Bulletin 67-3. DOI: https://doi.org/10.15201/hungeobull.67.3.1

Kozina, J., Clifton, N. 2019: City-region or urban-rural framework: what matters more in understanding the residential location of the creative class? Acta geographica Slovenica 59-1. DOI: https://doi.org/10.396/ AGS.5137

Lazzeretti, L., Capone, F., Innocenti, N. 2018: The rise of cultural and creative industries in creative economy research: a bibliometric analysis. Creative Industries and Entrepreneurship. Cheltenham. DOI: https://doi.org/10.4337/9781786435927.00007

Leong, L. Y. C., Fischer, R., McClure, J. 2014: Are nature lovers more innovative? The relationship between connectedness with nature and cognitive styles. Journal of Environmental Psychology 40. DOI: https://doi.org/10.1016/j.jenvp.2014.03.007

Martin-Brelot, H., Grossetti, M., Eckert, D., Gritsai, O., Kovács, Z. 2010: The spatial mobility of the »Creative Class«: A European perspective. International Journal of Urban and Regional Research 34-4. DOI: https://doi.org/10.1111/j.1468-2427.2010.00960.x

McGranahan, D., Wojan, T. 2007: Recasting the Creative Class to examine growth processes in rural and urban counties. Regional Studies 41-2. DOI: https://doi.org/10.1080/00343400600928285

Mell, I. C., Henneberry, J., Hehl-Lange, S., Keskin, B. 2013: Promoting urban greening: Valuing the development of green infrastructure investments in the urban core of Manchester, UK. Urban Forestry \& Urban Greening 12-3. DOI: https://doi.org/10.1016/j.ufug.2013.04.006

Muro, M., Rothwell, J., Saha, D. 2011: Sizing the clean economy: A national and regional green jobs assessment. Internet: http://www.brookings.edu/research/reports/2011/07/13-clean-economy (10.9.2018).

Musterd, S., Gritsai, O. 2013: The creative knowledge city in Europe: Structural conditions and urban policy strategies for competitive cities. European Urban and Regional Studies 20-3. DOI: https://doi.org/10.1177/ 0969776412439199

Plambech, T., Konijnendijk van den Bosch, C. 2015: The impact of nature on creativity - A study among Danish creative professionals. Urban Forestry \& Urban Greening 14-2. DOI: https://doi.org/10.1016/ j.ufug.2015.02.006 
Poljak Istenič, S. 2016: Reviving public spaces through cycling and gardening. Ljubljana - European Green Capital 2016. Etnološka tribina 39. DOI: https://doi.org/10.15378/1848-9540.2016.39.06

Poljak Istenič, S. 2019: Participatory urbanism: creative interventions for sustainable development. Acta geographica Slovenica 59-1. DOI: https://doi.org/10.396/AGS.5142

Pratt, A. C., Hutton, T. A. 2013: Reconceptualising the relationship between the creative economy and the city: Learning from the financial crisis. Cities 33. DOI: https://doi.org/10.1016/j.cities.2012.05.008

Ravbar, M. 2011: Creative social groups in Slovenia: contribution to geographic studying of human resources. Acta geographica Slovenica 51-2. DOI: https://doi.org/10.3986/AGS51204

Ravbar, M., Bole, D., Nared, J. 2005: A creative milieu and the role of geography in studying the competitiveness of cities: the case of Ljubljana. Acta geographica Slovenica 45-2. DOI: https://doi.org/10.3986/AGS45201

Schlesinger, P. 2017: The creative economy: invention of a global orthodoxy. Innovation: The European Journal of Social Science Research 30-1. DOI: https://doi.org/10.1080/13511610.2016.1201651

Scott, A. J., Storper, M. 2015: The nature of cities: The scope and limits of urban theory. International Journal of Urban and Regional Research 39-1. DOI: https://doi.org/10.1111/1468-2427.12134

Smrekar, A., Šmid Hribar, M., Erhartič, B. 2015: Stakeholder conflicts in the Tivoli, Rožnik Hill, and Šiška Hill Protected Landscape Area. Acta geographica Slovenica 56-2. DOI: https://doi.org/10.3986/AGS.875

Stolarick, K., Smirnova, O. 2015: Are creative and green cities also smart and sustainable? Smart Cities as Democratic Ecologies. London.

Uršič, M. 2016: Characteristics of spatial distribution of creative industries in Ljubljana and the Ljubljana region. Acta geographica Slovenica 56-1. DOI: https://doi.org/10.3986/AGS.745

Uršič, M., Tamano, K. 2019: The importance of green amenities for small creative actors in Tokyo: Comparing natural and sociocultural spatial attraction characteristics. Acta geographica Slovenica 59-1. DOI: https://doi.org/10.396/AGS.4710

Van Den Bogerd, N., Coosje Dijkstra, S., Seidell, J. C., Maas, J. 2018: Greenery in the university environment: Students' preferences and perceived restoration likelihood. PLoS ONE 13-2. DOI: https://doi.org/ 10.1371/journal.pone.0192429

van Rompay, T. J. L., Tineke, J. 2016: Wild and free: Unpredictability and spaciousness as predictors of creative performance. Journal of Environmental Psychology 48. DOI: https://doi.org/10.1016/j.jenvp.2016.10.001

WCED - World commission on environmental and development: Our common future - Brundtland report. Oxford, 1987.

White, P. 2010: Creative industries in a rural region: Creative West: The creative sector in the Western region of Ireland. Creative Industries Journal 3-1. 